\title{
ロボットマニピュレータの総合設計システムに関する研究
}

\author{
井上健 司*1 椎 名 建 一*2 高 野 政 晴*3 佐々木 健*3
}

\section{Study on Total Computer-aided Design System for Robot Manipulators}

\author{
Kenji Inoue ${ }^{* 1}$, Ken'ichi Shiina*2, Masaharu Takano*3 and Ken Sasaki*3
}

\begin{abstract}
A total computer-aided design system for robot manipulators "TOCARD" has been developed. This system determines all design parameters of a robot mechanism - not only the fundamental mechanism (degree of freedom, joint types, arm lengths and offsets) but also the inner mechanism (motor allocations, transmission mechanisms, motors, reduction gears, arm cross-sectional dimensions and machine elements). Analyzing the relationship between these parameters and design evaluation functions made it clear that the fundamental mechanism is tightly connected with kinematic functions and the inner mechanism with static/dynamic functions. Accordingly, the design procedure of "TOCARD" consists of three local optimization stages to make the robot design efficient. 1) The fundamental mechanism is designed based on kinematic evaluation such as workspace, effective degree of freedom, joint displacement, velocity and acceleration, and workpiece velocity and acceleration. 2) The motor allocations and transmission mechanisms are determined, and the arm cross-sectional dimensions and machine elements are calculated roughly, based on simple evaluation of dynamics - total motor power, total weight, deflection and weight capacity. 3) The arm cross-sectional dimensions and machine elements are modified based on precise evaluation of dynamics including natural frequency. "TOCARD" also has a robot simulator and the data base of machine elements.
\end{abstract}

Key Words : Robot, Manipulator, Robot Design, CAD, Robot Simulator

\section{1.はじめに}

産業界におけるロボットの需要が増大し，その適用範囲が人 間社会の様々な分野に広がるにつれて，ロボットに対する機能 の多様化や高速高精度化といった性能向上の要求もますます厳 しくなってきている. その結果, ロボットの設計に際して以下 の点が問題となってきた.

1）ロボットに要求される動作や性能が多種多様となるた め，そうした条件をすべて考慮してロボットを設計する 必要がある。特に，今までロボット化されていない作業 に対しては，過去に設計例のないタイプのロボットが求 められる可能性も有る.

2）ロボットは開ループリンク機構なので長い片持ちはり状 態となり，しかも関節駆動系には減速機や伝達機構が用

\section{原稿受付 1995 年 7 月 5 日}

*1大阪大学工学部

*2川崎情報システム(株)

*3東京大学工学部

${ }^{* 1}$ Faculty of Engineering, Osaka University

${ }^{*}$ Kawasaki Steel, Systems R \& A Co.

${ }^{*}$ Faculty of Engineering, University of Tokyo
いられるので, 剛性が低い構造となっている，剛性が低 いとたわみや振動のために精度が低下する。しかしなが ら，剛性を上げると重くなるため，高速動作ができなく なるとともに, 動力の多くをアームの駆動に費やしてし まい, 可搬重量/自重比が低下する. したがって, 高速高 精度化のためには, 設計の際にロボット各部分に対する 剛性と質量の配分を考え，剛性を必要量から落とさずに できるだけ軽量化を図ることが重要となる.

試作と実験を繰り返す従来の設計方法では，このような問題点 に対応するのは難しい. そこで, ロボット用の CAD システム の開発が期待されている，ロボット CAD システムでは，目的 作業によって決まる要求仕様を満足するロボットを設計できる とともに,設計に要する時間,費用を節約することが可能となる.

現在までに，コンピュータを用いたロボットの設計システム に関する研究がいくつか行われているが[1]〜 [12]，それらの 多くは設計パラメータの一部を最適化するものであり, 自由 度, 関節構成, アーム長といった基本機構の設計から内部機構 の設計，すなわち各関節を駆動するモータの配置とモータ〜関 節間の伝達機構の決定，アーム太さの設計，さらには使用する モー夕，減速機，軸受などの機械要素の選定までを一貫して行 
うシステムはまだない.

そこで本研究では，このようなロボットのメカニズムのあら ゆる設計パラメータの設計を行う総合 CAD システム “TOCARD (Total Computer Aided Robot Design)”を開発し た. “TOCARD”により，目的とする単一あるいは複数の作業 を実現できるロボットの設計が可能となる.

ロボットの総合的設計を行う場合, 前述のように設計パラメ 一タは多く, 設計のための評価量も作動領域, ワークの速度, 全モータパワー, 全重量, 可搬重量, 精度など多岐にわたって いるため，これらを一度に設計することは難しい．そこで，設 計パラメータと評価量の関係を調べた結果, 基本機構は運動学 的評価に, 内部機構は力学的評価に関係が深いことが明らかに なった.よって，ロボットの設計を運動学的評価に基づく基本 機構の設計と力学的評価に基づく内部機構の設計とに分けるこ とにより，設計システムを簡単にすることができる. “TOCARD”では，内部機構の設計をさらに 2 段階に分け，各 段階で局所的な最適化を図ることにより，ロボットを効率よく 設計する方法を提案する。すなわち,

1）作動領域, 関節速度, ワーク速度といった運動学的評価 のもとに基本機構を設計する.

2）全モータパワー, 全重量, たわみの大まかな評価に基づ いて, モー夕配置と伝達機構の種類を決定し, 同時にア 一ム太さの見積りと機械要素の仮選定を行う.

3）全重量, たわみ, 固有振動数の厳密な評価を行って, 見 積り・仮選定の結果を修正する.

設計は，設計者による設計変更と評価を繰り返す対話的設計を 基本とするが，a）ロボット設計熟練者の知識を利用したファ ジィ推論による性能の大まかな評価に基づく作業に適したロボ ットタイプの選定, b) 構造要素毎のたわみまたは強度評価に 基づくアーム太さおよび機械要素の自動見積り・仮選定，c）全 重量, たわみ, 固有振動数に対する感度解析を利用したアーム 太さと機械要素の修正および勾配射影法によるアーム太さの自 動最適化，といった独自の手法を用いて設計を支援するシステ ムを開発した。

\section{2. “TOCARD”の構成と設計手順}

\section{1 設計パラメータ}

はじめに, “TOCARD”が設計対象としているロボットのメ カニズムの適用範囲とその設計パラメータを示す

“TOCARD”では, Fig. 1のようにいくつかのリンクが回転 または直動関節によって直列に結合された開ループリンク機構 のロボットを対象とする. 開ループリンク機構のロボットにお いて,

1) 自由度

2）各関節の種類（回転あるいは直動）とその並び

3）アーム長・オフセット（より一般的には隣合う関節間の相 対位置姿勢関係)

は，運動学的な設計パラメータである．本研究では，これらを まとめてロボット基本機構と呼ぶことにする.

リンクや関節を実現している構造要素（以後，基本構造要素 と呼ぶ）としては Fig. 2 に示す,

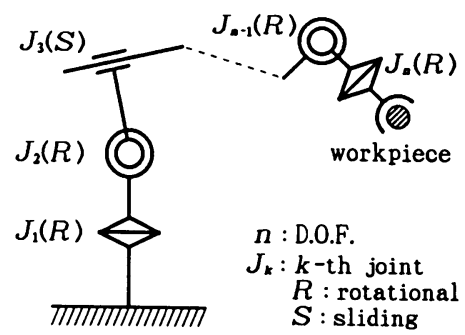

Fig. 1 Serial link manipulator

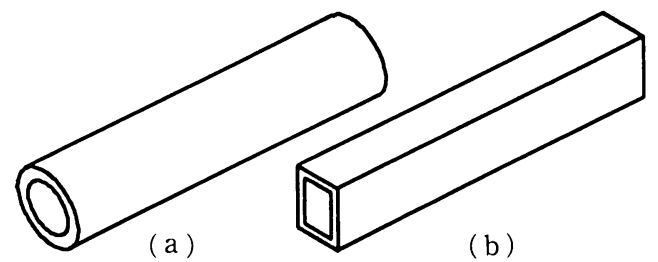

(b)

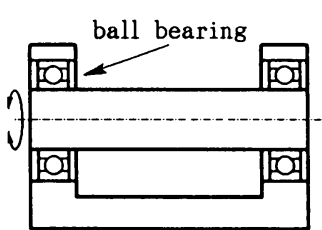

(c)

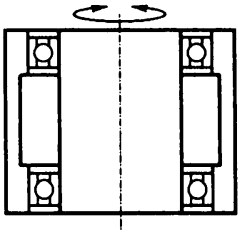

(d)

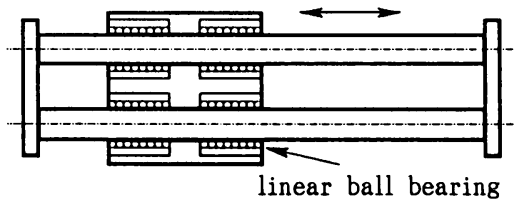

( e )

Fig. 2 Fundamental structure elements

(a ) 円筒型アーム要素

(b) 直方体型ア一ム要素

(c ) 旋回型回転関節要素

(d) 回転型回転関節要素

(e) 直動関節要素

の 5 種類を考えた.

一方，各関節を駆動するアクチュエータ・減速機としては, 電動モータとハーモニックドライブを想定した。前者は取扱い の容易さや制御性, 保守性といった面から, 後者は軽量, コン パクトで高減速比を有することから，現在多くの産業用ロボッ トに使われている. Fig. 3 の第 1 ，第 5 関節のように，モー 夕・減速機を関節軸上に置く配置をモー夕の直接配置，第 $2 \sim 4$ 関節のように伝達機構を介して別の場所に置く方式を間接配置 と呼ぶことにする。

そこで, 関節駆動系を構成している要素として
(a) モー夕・減速機要素
(b) 軸要素
(c) チェーン・スプロケット要素
(d) かさ歯車要素
(e ）ボールネジ・ナット要素

の 5 種類を考え，これらを駆動系要素と呼ぶことにする. 


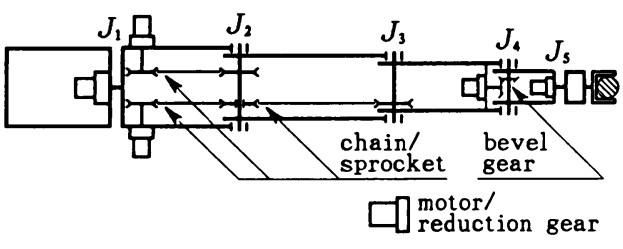

Fig. 3 An example of inner mechanisms

以上述べてきた

4) モー夕配置

5）伝達機構の種類

6) モー夕

7) 隇速機と減速比

8）アーム太さ（より一般的には基本構造要素の寸法と材質）

9) 機械要素（軸受，チェーン，かさ歯車など）

は，すべて力学に関係した設計パラメータとなっている. そこ で本研究では，これらをまとめてロボット内部機構と呼ぶこと にする.ただし，6），7），9）はカタログから選定する.

\section{2 設計条件}

“TOCARD”では，目的とする単一あるいは複数の作業を実 現できるロボットを設計する，そこで，目的作業によって決ま る設計条件として，以下を入力することとする.

1）エンドエフェクタを含めたワークの大きさと質量

2）作業に含まれる単一あるいは複数の手先軌道

3）作業を行う領域

4）手先の許容たわみと許容固有振動数

後述するように，本研究では精度に影響を与える要因のう ち，剛性のみを考えることにした。したがって，4）は精度に対 する制約条件を間接的に表したものである.

専用機械と比べたロボットの大きな特徴は, 自由度が高いの で複雑で多様な動作ができ，その軌道プログラムとエンドエフ エクタを取り替えることで様々な作業を実現できるという汎用 性にある。ワークや軌道が異なれば，必要なモータパワーや手 先に生じるたわみといったロボットの性能も変わってくるた め, 複数の目的作業を実現できるロボットを設計するには，作 業に扱われるすべてのワークと軌道を設計条件として与える必 要がある. その一方で, 条件となるワークと軌道が無数にある と，計算時間が問題となる．これに対して“TOCARD”で は，(1)作業に典型的なワークと軌道をいくつか選び，それらを 条件としてロボットを設計する，(2)設計したロボットが他のワ ークや軌道にも適用できるかをサブシステムのロボット・シミ ュレータを用いてチェックする, (3)適用できないワークや軌道 があった場合には，それらを条件に追加して設計をやり直すこ ととする.

\section{3 設計における評価量}

ロボットのメカニズムの設計における評価量としては, 以下 が考えられる.

1）有効自由度

ロボットの設計や選定の際には，目的作業に対する基本機構 の適性を評価することが重要となる[13][14]．ロボットの作業 の基本はワークを目標軌道に沿って動かすことなので, 目標軌

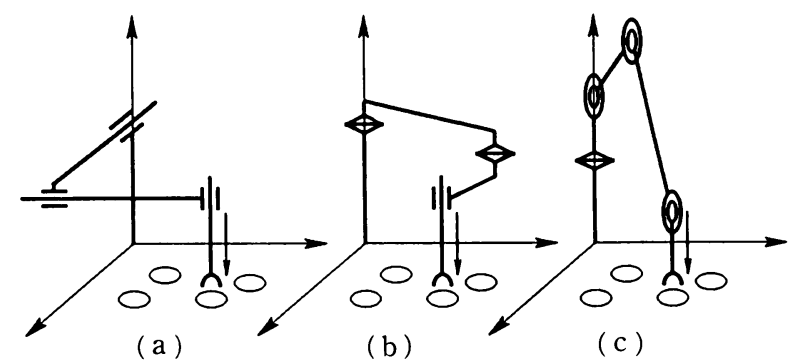

(b)

(c)

Fig. 4 Three types of robots used in the assembly task

道を容易に実現できるかが，作業に対する基本機構の適性評価 となり得る。そのような指標として, 本研究では有効自由度と いう概念を新たに提案する．例えば，Fig.4のように平面上の 複数の穴に部品を垂直に挿入する作業の場合, 図に示す 3 つの ロボットはどれでもこの作業を実現できる，ところが，（a ）と (b)のロボットは手先の直動関節の 1 自由度で容易に挿入でき るのに対し，（c）のロボットでは第 2 関節から第 4 関節の 3 つ の回転関節を同時に動かさなければ垂直に挿入することができ ない. 平面上の目標軌道を動かす場合でも，（c）のロボットで は目標位置間で 3 次元的な誤差が生じやすいのに対して,

( a )，（b ）のロボットはベースに近い 2 自由度のみを動かすの で，平面内での運動は保証されている，以上のことから，ロボ ットが目標軌道上を運動する際に，同時に動かす自由度数が少 ないほど容易にその軌道を実現できるという評価が成り立つ. そこで，この同時に動かす自由度数を表す指標を有効自由度と いい,これが小さいほど目標軌道に適していると評価できる. 有効自由度の定義は次章に示す.

\section{2）作動領域}

作動領域は基本機構に樑く関係した評価量で, 設計条件の作 業を行う領域を覆っていなければならない.

\section{3）関節可動範囲}

直動関節の可動範囲は直動軸の長さによって決まる. 回転関 節の場合は, Fig. 2(d)の関節なら一回転できるが, （c）の関 節では構造上関節変位が制限される. 関節可動範囲が広いほど ロボットの作動領域は広がるが, 必要以上に長い直動軸は重量 を増加させるし，（c）の回転関節にオフセットを付けると回転 軸が片持ちとなって構造上好ましくない場合もある. そこで, 設計条件の軌道を運動させたときに，関節変位がその可動範囲 内にあれば十分であると考える。

4）関節の最大速度・加速度

5）ワークの最大速度・加速度

6）モータの最大駆動トルク

ワークの最大速度・加速度は関節最大速度・加速度とアーム 長に，関節最大速度・加速度はモータの駆動能力とアーム重量 に深く関係しており，これらは軌道にも影響される．作業に要 求されるワークの最大速度・加速度は，作業に含まれる手先軌 道を設計条件とすることで間接的に与えられる.このとき，与 えられた軌道を運動する際の関節最大速度・加速度とアーム長 を小さくするように基本機構を決めた上で, アーム太さを変え てアーム重量を調整することにより，駆動に必要なモータの最 
Table 1 Relationship between design parameters and evaluation functions

\begin{tabular}{|c|c|c|c|c|c|c|c|c|c|c|c|c|c|c|}
\hline \multirow{2}{*}{\multicolumn{2}{|c|}{$\begin{array}{r}\text { evaluation } \\
\text { function }\end{array}$}} & \multicolumn{5}{|c|}{ kinematics } & \multicolumn{6}{|c|}{ dynamics } & \multicolumn{2}{|c|}{ both } \\
\hline & & 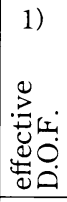 & 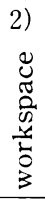 & 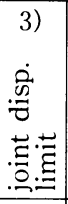 & 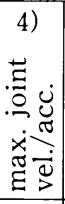 & 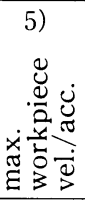 & 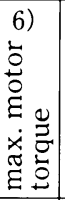 & 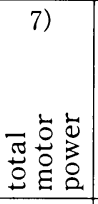 & 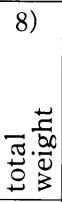 & 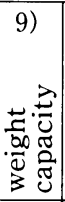 & 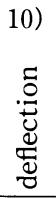 & 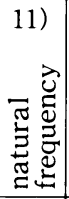 & 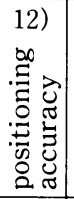 & $\begin{array}{l}\text { 13) } \\
\text { क् } \\
0\end{array}$ \\
\hline \multirow{4}{*}{ 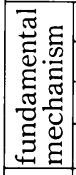 } & 1) D. O. F. & (O) & (O) & $\triangle$ & $\triangle$ & $\triangle$ & $\Delta$ & 0 & 0 & $\Delta$ & 0 & 0 & 0 & (C) \\
\hline & 2) joint type & (C) & (9) & 0 & $\triangle$ & $\triangle$ & $\triangle$ & 0 & $\bigcirc$ & $\triangle$ & O & 0 & 0 & (a) \\
\hline & 3) arm length & (2) & (O) & $\triangle$ & (2) & (C) & (O) & (O) & (9) & (C) & (a) & (2) & (C) & O \\
\hline & 3) offset & (9) & (C) & (2) & $\triangle$ & $\triangle$ & $\triangle$ & $\triangle$ & $\triangle$ & 0 & $\triangle$ & $\triangle$ & $\triangle$ & $\triangle$ \\
\hline \multirow{6}{*}{ 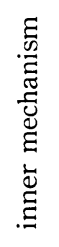 } & 4) motor allocation & $\triangle$ & $\triangle$ & $\triangle$ & $\triangle$ & $\triangle$ & (a) & (Q) & (a) & (C) & $\triangle$ & $\triangle$ & $\triangle$ & $\triangle$ \\
\hline & 5) trans. mech. & $\triangle$ & $\triangle$ & (2) & $\triangle$ & $\triangle$ & $\triangle$ & $\triangle$ & (C) & $\triangle$ & (C) & (2) & (O) & (a) \\
\hline & 6) motor & $\triangle$ & $\triangle$ & $\triangle$ & (C) & (C) & (0) & (0) & (2) & (C) & $\triangle$ & $\triangle$ & $\triangle$ & (2) \\
\hline & 7) reduction gear & $\triangle$ & $\triangle$ & $\triangle$ & (C) & (9) & (O) & (O) & (C) & (C) & () & (2) & (O) & (a) \\
\hline & 8) arm cross. dim. & $\triangle$ & $\triangle$ & $\triangle$ & $\triangle$ & $\triangle$ & (C) & $\triangle$ & (C) & (C) & (a) & (O) & (2) & 0 \\
\hline & 9) machine element & $\triangle$ & $\triangle$ & $\triangle$ & $\triangle$ & $\triangle$ & (C) & $\triangle$ & (a) & (C) & (C) & (2) & ()) & 0 \\
\hline
\end{tabular}

(): strong $\bigcirc$ : medium $\triangle$ : weak

大トルクを隇らすことが可能となる。モータ駆動トルクには, モータ配置も大きく影響する．例えば，Fig. 3 のように，関節 $J_{3}$ を駆動するモー夕を他の関節 $J_{2}$ を通り抜けてベース側に置 く場合，通り抜けられた $J_{2}$ のモータは， $J_{3}$ のモー夕駆動卜ル クの反力と $J_{3}$ のモータ重量を支える必要がないので少ないト ルクですみ，モー夕を小型化できる，また，間接配置ではモー 夕を運動のじゃまにならない場所におけるという利点もある. その反面，伝達機構を入れると剛性が下がったり，通り抜けの 数を多くすると機構が複雑になり, かえって重量の増加を招く こともある.

7）全モータパワー

8) 全重量

これらを小さくすることは，コストの低隇にもつながる当然 の要求である. 軽量化は, 高速動作を可能にするだけでなく, ロボットの輸送や設置の容易さといった面でも重要となる.

9) 可搬重量

モータの駆動能力の一部はアームの駆動に費やされ，残りが ワークの移動に使われる。よって，可搬重量は，モー夕の駆動 能力とアーム長およびアーム重量によって決まる。ロボットに は, 設計条件として与えたワーク重量を支えられるだけの可搬 重量が要求される.

10）たわみ

11) 固有振動数

たわみと固有振動数はロボット各部の剛性と重量に関係した 評価量であり，高速高精度化のためには，これらを設計条件の 許容範囲内に収めつつできるだけ軽量化を図る必要がある.

12）精度

精度に影響を与える要因としては, 加工・組立誤差やセンサ の分解能, 機械要素の精度, 摩擦, 制御系に起因する誤差, お よびメカニズムの剛性が挙げられるが，ここではメカニズムの 剛性のみを考える.したがって，精度はたわみと固有振動数に よって間接的に評価される。

13) コスト
コストを正確に見積もることは非常に難しいが，一般には， 重量が小さく, 必要なモータパワーが少ないほどコストは安く なる。そこで, 全重量および全モータパワーを小さくすること で，間接的にコストを評価する.

以上に加えて, 個々のアームや機械要素, 減速機は, それら に作用する内力に対して必要十分な強度, 剛性を持っていなけ ればならない. 各モー夕も, 駆動に必要なパワー・トルク以上 の能力を持つものを選定しなければならない.

\section{4 設計パラメータと評価量の関係の深さ}

以上述べてきた設計パラメータと設計のための評価量の関係 の深さをまとめると, Table 10ようになる.この表から, 口 ボット基本機構は運動学的評価に, 内部機構は力学的評価に関 係が深いことがわかる.もちろん，両者は完全に分離されてい るわけではない. しかしながら，基本機構を設計する際に，ア 一ム長あるいはその総和であるロボット全長をできるだけ小さ くし，自由度を少なくすれば，すべての力学的評価は望ましい ほうに改善される. よって, 基本機構を設計する際の力学的評 価を, ロボット全長と自由度の評価という形で間接的に行うこ とができる.

以上のことから，ロボットの設計を運動学的評価に基づく基 本機構の設計と力学的評価に基づく内部機構の設計とに分ける ことにより，設計システムを簡単にすることが可能となる.

\section{5 “TOCARD” の特徵}

そこで本研究では, 以下の特徴を持つロボット総合 CAD シ ステム“TOCARD”を開発した。

1）ロボットのメカニズムの設計を目的とする. 特に, 基本機 構だけでなく内部機構に至るまでの総合的設計を行う.

2）目的とする単一あるいは複数の作業を実現できるロボッ トを設計する。

3）基本機構は運動学的評価に基づいて設計し，内部機構は 力学的評価のもとに設計する.

4) 設計は基本機構設計, 内部機構設計, 詳細設計の 3 段階 に分けて行い, 各段階で局所的な最適化を図る. 途中で 
野政 晴佐々木 健

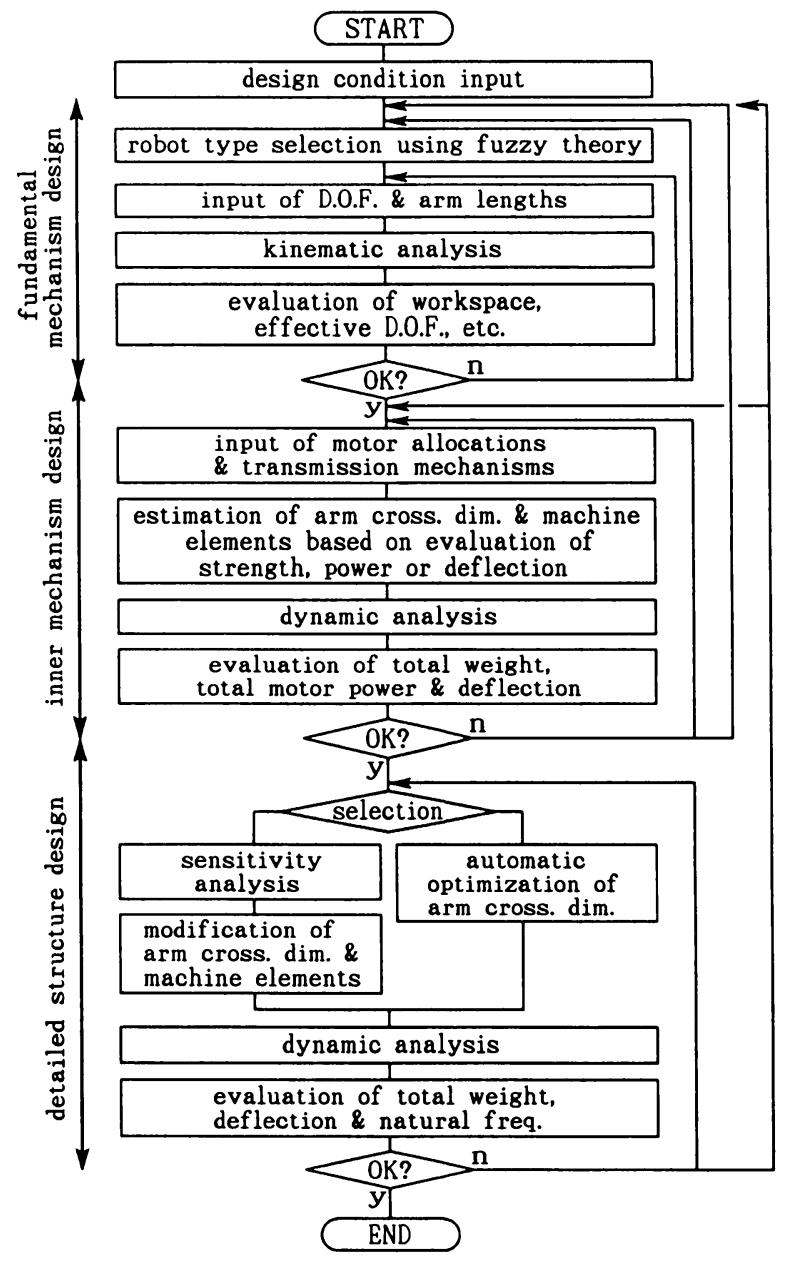

Fig. 5 Total robot design procedure in "TOCARD"

設計に不具合が生じた場合は，前段階に戻って設計をや り直す。

5）設計者による設計変更と評価を繰り返す対話的設計を基 本とし，これを支援する独自の設計手法を有する.

6）設計に必要な解析のためのロボット・シミュレータを備え ている.このシミュレータは, 独立して使うこともできる，

7）機械要素はカタログから選定するため, 機械要素データ ベースおよびデータベース作成ツールも備えている.

\section{6 “TOCARD” の設計手順}

目的作業によって決まる設計条件の入力から全設計パラメー 夕の決定に至るまでのロボットの総合的設計手順を Fig. 5 に 示す. 2.5 節の 4)で述べたように，設計手順は大きく分けて以 下の 3 段階から成る.

1）基本機構設計

有効自由度，作動領域，関節速度，ワーク速度といった 運動学的評価のもとに基本機構を設計する.

2) 内部機構設計

全モータパワー, 全重量, たわみの大まかな評価に基づ いて, モー夕配置と伝達機構の種類を決定し, 同時にア ーム太さの見積りと機械要素の仮選定を行う.

3) 詳細設計
全重量, たわみ, 固有振動数の厳密な評価を行って, 見 積り・仮選定の結果を修正する. 各設計段階の詳細は，それぞれ第 $4,5,6$ 章で述べる.

$$
\text { 3. ロボット・シミュレータ }
$$

“TOCARD”は，ロボットのメカニズムの設計に必要な以下 の解析システムを備えている[15].このうち，1＜wide>５）は運動学 的な解析で, 基本機構のみが決まれば計算できる。これに対し て 6)〜8) は力学的な解析で, 各要素の形状や大きさ, 質量, 剛性までも考えたロボットの剛体または弾性体モデルが必要と なる.各解析の詳細は文献にゆずり，以下にその概要をまとめる.

\section{1) 順運動学解析 (位置解析)}

関節変位べクトル $\boldsymbol{q}$ を与えてワークの位置姿勢 $\boldsymbol{R}$ を求める 順運動学には, Denavit-Hartenberg の方法を修正した座標変 換マトリックスを用いる[16].

\section{2) 逆運動学解析}

筆者らは， $\boldsymbol{R}$ を与えて $\boldsymbol{q}$ を求める逆運動学の効率よい解法 を開発した [16].この方法は，手先の 3 関節が回転関節のあら ゆる 6 自由度ロボットに適用でき, 最大 8 組の解が同時に得ら れる.

\section{3）作動領域解析}

筆者らが開発した方法[17]は，ロボットの設計において重要 なべースに近い 3 自由度による作動領域の境界を，あらゆる関 節構成のロボットについて求めることができる.

\section{4) 速度加速度解析}

Luh の逆動力学のアルゴリズム[18]は， $\boldsymbol{q}, \dot{\boldsymbol{q}}, \ddot{\boldsymbol{q}}$ からワーク の速度 $\boldsymbol{v}$, 加速度 $\boldsymbol{a}$ を求める部分を含んでいるので, これを 用いた。

\section{5）有効自由度解析}

目標軌道に沿って始点から測ったワークの移動距離（または 時間）を $u$, 軌道上の点 $\boldsymbol{R}(u)$ における各関節変位を $q_{\boldsymbol{k}}(u)$ $\left(k=1, \cdots, n ; n\right.$ は自由度), $q_{k}(u)$ の軌道に沿った変化率の大 きさを $\theta_{k}(u) \equiv\left|d q_{k}(u) / d u\right|$, これを大きい順に並べ変えたもの を $\theta_{g k}(u)$ としたとき， $u$ における有効自由度 $n_{e}(u)$ を次式で 定義する.

$$
n_{e}(u) \equiv 2 \sum_{k=1}^{n}\left(\theta_{g k} \cdot k\right) / \sum_{k=1}^{n} \theta_{g k}-1
$$

軌道における $n_{e}$ の代表值としては，uに関する平均 $\overline{n_{e}}$ を考 える. $\theta_{g k}$ が大きい順に並んでいるために，有効自由度は同時 に動かす関節数が多いほど大きく，また同数の関節を動かす場 合でも，各 $\theta_{g k}$ が等しいほど大きくなる。このように，有効自 由度は， $\theta_{g k}$ の比に基づいて，ロボットが目標軌道上を運動す る際に同時に動かす自由度数を評価するものである.

6) 逆動力学解析

本研究では，Luhのアルゴリズムを Fig. 3 のような伝達機 構を持つロボットにも適用できるように拡張し，これを用い て, $\boldsymbol{q}, \dot{\boldsymbol{q}}, \ddot{\boldsymbol{q}}$ および外力 $\boldsymbol{F}$ からモー夕駆動トルク $\tau_{m}$ を求め る.この方法は, 駆動トルクだけでなく各要素に働く内力も計 算するので，要素の強度，たわみ解析にも利用できる.

\section{7）たわみ解析}

8）固有振動解析 
一般に，関節部の軸受，減速機，伝達機構の剛性はアームの 剛性に比べて小さいので, これらを無視することはできない. そこで本研究では，伝達機構を持つロボットにも適用でき，ア 一ムだけでなく軸受, 減速機, 伝達機構の剛性も考慮した有限 要素法によるロボットの弾性体モデルを考え, $\boldsymbol{q}, \dot{\boldsymbol{q}}, \ddot{\boldsymbol{q}}, \boldsymbol{F}$ を

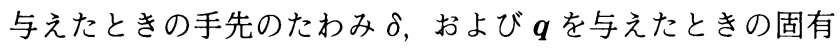
振動数 $f$ を求める $[19]$.

9) 機械要素データベース

“TOCARD”は，機械要素および材料のデータベースとその 作成ツールも備えている，ここで管理するデータは，大きく 2 種類に分けられる。ひとつは上記の解析に必要な材料の密度, 縦弾性係数, 横弾性係数, 機械要素の寸法, 重量, 剛性であ る.もうひとつは内部機構の設計に用いるデータで, 材料の許 容応力, 機械要素の許容トルクや許容荷重, 許容回転速度, お よびモー夕の定格出力である.

10）軌道生成

さらに，設計条件となる軌道を生成するシステムも持ってい る. 軌道は，以下の 4 種類の組合せで与えられる.

（a）始点, 終点と移動時間が与えられたとき, 各関節がそ れぞれ台形速度曲線で運動する PTP 軌道

（b）複数の点とその通過時刻が与えられたとき，それらを 通る CP 軌道

（c）始点, 終点と移動時間が与えられたとき，手先が直線 運動する補間軌道

（d）始点, 通過点, 終点と移動時間が与えられたとき，そ れらを通る手先の円弧補間軌道

\section{4. 基本機構設計}

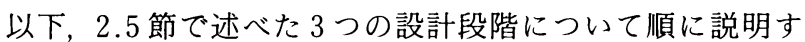
る.

最初に，運動学的評価のもとに基本機構を設計する. Fig. 5 に示すように，基本機構設計は大きく 2 つの段階からなる.

Step 1：現在の産業用ロボットのほとんどは,

・直角座標ロボット

・円筒座標ロボット

・極座標ロボット

・垂直多関節ロボット

・水平多関節ロボット

に分類できる。そこでまず，これらの中から目的作業に適した ロボットタイプを選定する．選定を行うためにはロボットの性 能を評価しなければならないが，ロボットタイプだけでは性能 を厳密に計算することができない。しかしながら，ロボットの 設計熟練者は, 各ロボットタイプがどのような性能の特徴を持 っているかを経験的に知っている. そこで本研究では, それら の経験的知識と作業に要求される性能とをファジィ理論を用い て大まかに比較することにより，作業に適したロボットタイプ を選定する方法を新たに考えた $[20]$. 以下にその概要を述べ る.ここで, 例の下線部が, ファジィ集合で表現される部分で ある。

1）選定の際に評価する性能として, 設計熟練者が考慮して いる作動領域, 器用さ, 速度, 精度, 可搬重量の 5 つを
考え, これらとロボットの作業に対する適合度をファジ イ集合で表すことにする.

例：作動領域が広い. 作業に適している.

2）設計熟練者が持つ各ロボットタイプの性能に関する経験 的知識を，ファジィ事実の形で表す。こうした知識はす べて，予めシステムの中に用意しておく。

例：垂直多関節ロボットの作動領域は非常に広い.

3）設計者は，目的作業に要求される各性能をファジィ規則 の集合に表現し，入力する.

例：作動領域が広ければ，塗装作業に適している. 作動領域が狭ければ，塗装作業に全く適さない.

4）2）と 3) から, 多重ファジィ推論（Mamdani の方法）によ り各ロボットタイプの作業への適合度を求める.

例：垂直多関節ロボットは,塗装作業に非常に適している.

5) すべてのロボットタイプの適合度を求め, 最も適したロ ボットタイプを選定する.

Step 2：運動学的評価を行いながら対話的に設計変更を繰 り返し, 自由度およびアーム長・オフセットを决定する. 2.3節, 2.4 節で述べた各評価量の評価基準を以下にまとめておく.

1）設計条件の目標軌道における有効自由度を小さくする。

2）作動領域が，設計条件の作業を行う領域を覆つている.

3）ロボットが目標軌道上を運動するとき，各関節変位がそ の可動範囲内にある.

4）目標軌道における各関節の最大速度・加速度を小さくす る。

5）作業に要求されるワークの最大速度・加速度は，目標軌道 として間接的に与えられる.

6) ロボット全長を小さくする.

7）ロボットを目標軌道に沿って動かしたとき，全く動かさ ない関節があれば，削除して自由度を減らす。

Step 1のロボットタイプの選定では大まかに性能を評価し ただけなので, Step 2 の結果に不具合があればStep 1 に戻 り, 次に適したロボットタイプに変更する. 以上を繰り返し て，基本機構を決定する.

\section{5. 内部機構設計}

ここでは, 大まかな力学的評価のもとにモー夕配置と伝達機 構の種類を決定し, 同時にアーム太さの見積りと機械要素の仮 選定を行う.内部機構設計は，大きく 3 つの段階からなる。

Step 1：設計者が，Fig.6のようにモー夕配置と伝達機構の 種類を入力する.

Step 2 : システムが, 要素毎のたわみまたは強度評価に基づ いてアーム太さの見積りと機械要素の仮選定を行う。要素 $e_{i}$ の設計パラメータは, 手先側の要素 $e_{i+1}$ から受ける力とモー メント $\boldsymbol{F}_{i+1}$ を用いて決定できる (Fig. 7). その結果, $e_{i}$ の質 量 $m_{i}$, 重心位置 $\boldsymbol{r}_{g i}$, 慣性テンソル $\boldsymbol{I}_{i}$ が決まるので, 設計条 件の目標軌道に対して $e_{i}$ の逆動力学解析を行うことにより, $e_{i}$ がベース側の要素 $e_{i-1}$ に及ぼす力とモーメント $\boldsymbol{F}_{i}$ が計算で きる. そこで, 手先に近い要素から，上述の要素の設計と逆動 力学解析を交互に繰り返すことにより, 見積り・仮選定を行 う。以下に，各要素の見積り・仮選定の方法をまとめる. 


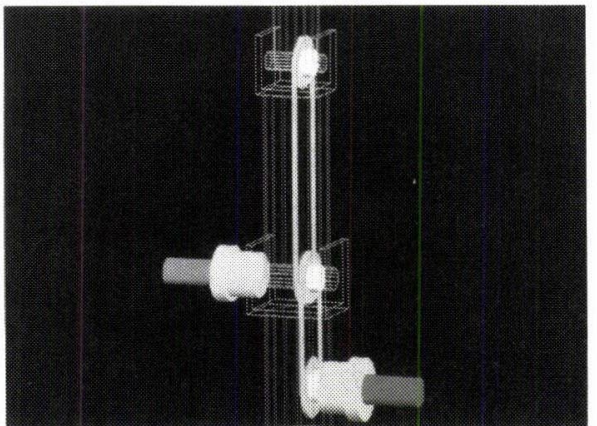

Fig. 6 An example of designed transmission mechanisms

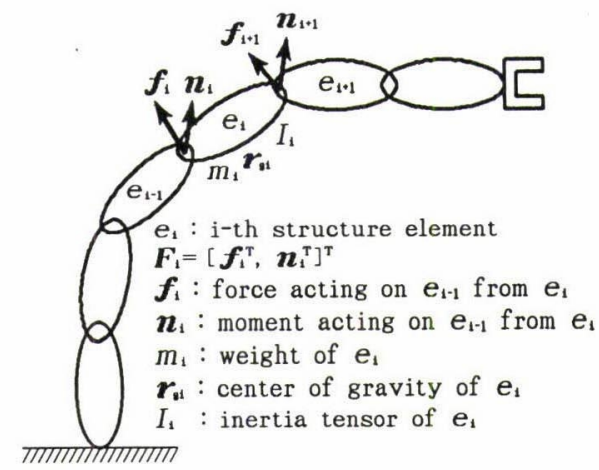

Fig. 7 Automatic estimation of each structure element in the inner mechanism design

1）アーム太さは，作用する最大力に対するアームのたわみ が許容範囲内にあり，かつアームが最も軽くなるように 決定する.

2）モータは，ロボットを動かすのに必要十分なパワー，ト ルクを持つ最も軽いものを選定する。

3）減速機や機械要素は, 作用する最大力または最大卜ルク 以上の許容荷重, 許容トルクを持つ最も軽いものを選定 する。

4）減速機の減速比は, 機械インピーダンスマッチングによ り決定する。

Step 3 : 以上でロボットの全設計パラメータが仮決定された ので, 力学的解析が可能となる. 設計者は, 以下のように 2.3 節で述べた力学的評価を行う.

1）目標軌道におけるモータの最大駆動トルクを小さくす る.

2）全モータパワーを小さくする.

3）全重量を小さくする.

4）作業に要求される可搬重量は, 設計条件のワーク重量と して間接的に与えられる。

5）目標軌道における最大たわみを設計条件の許容たわみに 近づける.

6）固有振動数は，ここでは評価しない.

5), 6)の設計条件は, 次の詳細設計で峳密に検討される.

設計者は，モー夕配置と伝達機構の種類をいろいろ変えて上 記の 3 段階を繰り返し, モータ配置と伝達機構の種類を決定す
る.このとき, Step 2 において, システムが自動でアーム太 さの見積りと機械要素の仮選定を行ってくれるので, 設計者の 手間と時間は軽減される.

\section{6. 詳 細 設 計}

第 1 章で述べたように, ロボットの高速高精度化のために は，たわみと固有振動数を許容範囲内に収めつつできるだけ軽 量化を図ることが重要である。ところが，内部機構設計におけ る見積り・仮選定は要素毎の局所最適化であり，ロボット全体 のたわみや固有振動数を考えた質量と剛性の配分が十分ではな い. そこで詳細設計 [19]では, 設計条件の許容たわみと許容固有 振動数の制約条件のもとに，全重量を最小にするようアーム太 さと機械要素を修正し，ロボット全体に関する最適化を図る.

ロボット全重量を $m$, 設計条件の目標軌道における最大た わみを $\delta$, 最小固有振動数を $f$, 許容たわみを $\delta_{0}$, 許容固有振 動数を $f_{0}$ とすると, 詳細設計における設計目標は,

$$
\begin{aligned}
& \text { 目的関数: } m \rightarrow \text { min. } \\
& \text { 制約条件 : } \delta \leqq \delta_{0}, f \geqq f_{0}
\end{aligned}
$$

となる. 本研究では, これを次式の拡大目的関数 $Q$ を最小に する問題に置き換えて考える.

$$
Q \equiv m+\frac{w_{d}}{\delta_{0}^{2}}\left\{\max \left(0, \delta-\delta_{0}\right)\right\}^{2}+\frac{w_{f}}{f_{0}^{2}}\left\{\max \left(0, f_{0}-f\right)\right\}^{2} \rightarrow \min .
$$

ここで, $w_{d}, w_{f}(>0)$ は制約条件に対するぺナルティで, $\delta_{0}, f_{0}$, $w_{d}, w_{f}$ が 2.2 節の設計条件として入力される.

Step 1：“TOCARD”では, 以下の 2 つの方法により, 設計 者が式（4）の設計を対話的に行うのを支援する.

1）感度解析を利用したアーム太さ・機械要素の対話的設計

対話的設計では，どの設計パラメータを修正すれば目的関数 を改善できるかがわかれば，設計者にとって有用である，本研 究では，そのような情報として感度を用いる。設計パラメータ $p$ の感度 $S_{p}$ は, 次式で定義される.

$$
S_{p} \equiv \partial Q / \partial p
$$

明らかに, 感度の大きいパラメータほど $Q$ を小さくするのに 効果がある，そこで，システムがすべてのアーム太さ・機械要 素の感度を計算し，設計者が最も感度のよいパラメータを選ん で修正する。

2) アーム太さの自動最適化

アーム太さは連続変数なので, 最適化しやすい. そこで, ア 一ム太さの取り得る範囲を制約条件として与え，勾配射影法に より，Qを最小にするアーム太さをシステムが計算する.

Step 2：設計変更後, 設計者は式 $(2)(3)$ に従って全重量, たわみ，固有振動数を評価する.

以上の設計変更と評価を繰り返してアーム太さと機械要素が 決定されると, “TOCARD”によるロボットの設計は終了する.

\section{7. 設 計 例}

本章では, “TOCARD”を用いて設計したロボットの例を示す. まず，設計条件を Table 2, Fig. 8， Fig.9にまとめる.

次に, 設計されたロボットを Fig. 10 に，その主な設計パラ メー夕を Table 3, Table 4, Table 5 に示す。また, ロボット 
Table 2 Typical workpiece, allowable deflection and allowable natural frequency given as design conditions

\begin{tabular}{lc|rc}
\hline length of workpiece & & 100.0 & {$[\mathrm{~mm}]$} \\
weight of workpiece & & 2.0 & {$[\mathrm{~kg}]$} \\
\hline allowable deflection & $\delta_{0}$ & 0.5 & {$[\mathrm{~mm}]$} \\
allowable natural frequency & $f_{0}$ & 25.0 & {$[\mathrm{~Hz}]$} \\
penalty for deflection & $w_{d}$ & 10000.0 & {$[\mathrm{~kg}]$} \\
penalty for frequency & $w_{f}$ & 10000.0 & {$[\mathrm{~kg}]$} \\
\hline
\end{tabular}

Table 3 Arm parameters of designed robot

\begin{tabular}{c|c|c|c}
\hline arm & length $[\mathrm{mm}]$ & diameter $[\mathrm{mm}]$ & thickness $[\mathrm{mm}]$ \\
\hline$B_{0}$ & 320.0 & 130.0 & 9.0 \\
$B_{1}$ & 320.0 & 120.0 & 10.0 \\
$B_{2}$ & 400.0 & 120.0 & 2.0 \\
$B_{3}$ & 280.0 & 84.0 & 2.0 \\
$B_{4}$ & 120.0 & 84.0 & 2.0 \\
$B_{5}$ & 120.0 & 84.0 & 2.0 \\
$B_{6}$ & 40.0 & 44.5 & 2.0 \\
\hline total & 1600.0 & & \\
\hline
\end{tabular}

cylinder type (See Fig. 2), duralumin

Table 4 Joint parameters of designed robot

\begin{tabular}{c|c|c|c}
\hline joint & $\begin{array}{c}\text { type } \\
\left(\begin{array}{c}\text { See } \\
\text { Fig. 2 }\end{array}\right)\end{array}$ & $\begin{array}{c}\text { distance } \\
\text { between } \\
\text { bearings } \\
{[\mathrm{mm}]}\end{array}$ & $\left.\begin{array}{c}\text { bearing } \\
\text { internal } \\
\text { diameter } \\
{[\mathrm{mm}]}\end{array}\right)$ \\
\hline$J_{1}$ & (d) & 80.0 & $6812(60.0)$ \\
$J_{2}$ & (c) & 140.0 & $6809(45.0)$ \\
$J_{3}$ & $(\mathrm{c})$ & 106.0 & $6807(35.0)$ \\
$J_{4}$ & $(\mathrm{~d})$ & 60.0 & $6808(40.0)$ \\
$J_{5}$ & (c) & 100.0 & $6804(20.0)$ \\
$J_{6}$ & (d) & 40.0 & $6805(25.0)$ \\
\hline
\end{tabular}

Table 5 Joint driving system parameters of designed robot

\begin{tabular}{c|c|c}
\hline joint & $\begin{array}{c}\text { motor } \\
\text { (rated power [W]) }\end{array}$ & $\begin{array}{c}\text { harmonic drive } \\
\text { (reduction ratio) }\end{array}$ \\
\hline$J_{1}$ & L 402-011 ( 23.0) & FRS-20-160 (160) \\
$J_{2}$ & L 720-012 (200.0) & CSS-32-160 (160) \\
$J_{3}$ & L 511-012 (110.0) & CSS-32-160 (160) \\
$J_{4}$ & L 402-011 (23.0) & CSS-20-80 ( 80) \\
$J_{5}$ & R 301-011 ( 11.0) & FRS-20-160 (160) \\
$J_{6}$ & R 301-011 (11.0) & CSS-20- 50 ( 50) \\
\hline
\end{tabular}

Table 6 Performance of designed robot

\begin{tabular}{l|rl}
\hline $\begin{array}{c}\text { mean effective D. O. F. } \\
\text { on given trajectory }\end{array}$ & 4.14 & \\
\hline total motor power & 378.0 & {$[\mathrm{~W}]$} \\
\hline total weight & 24.0 & {$[\mathrm{~kg}]$} \\
\hline $\begin{array}{c}\text { maximum deflection } \\
\text { on given trajectory }\end{array}$ & 0.468 & {$[\mathrm{~mm}]$} \\
\hline $\begin{array}{c}\text { minimum natural frequency } \\
\text { on given trajectory }\end{array}$ & 25.0 & {$[\mathrm{~Hz}]$} \\
\hline
\end{tabular}

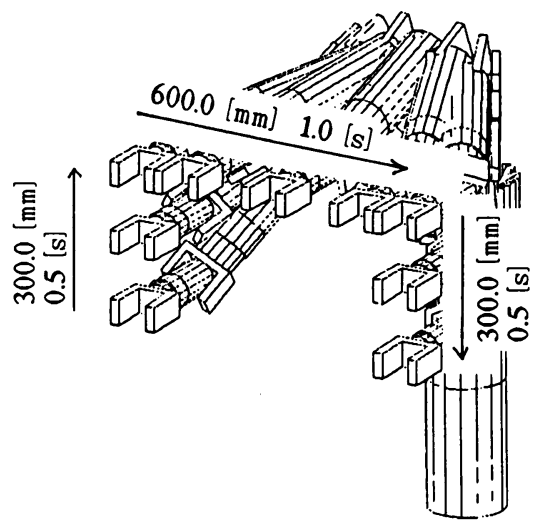

Fig. 8 Typical trajectory given as design condition and animation of designed robot moving along it

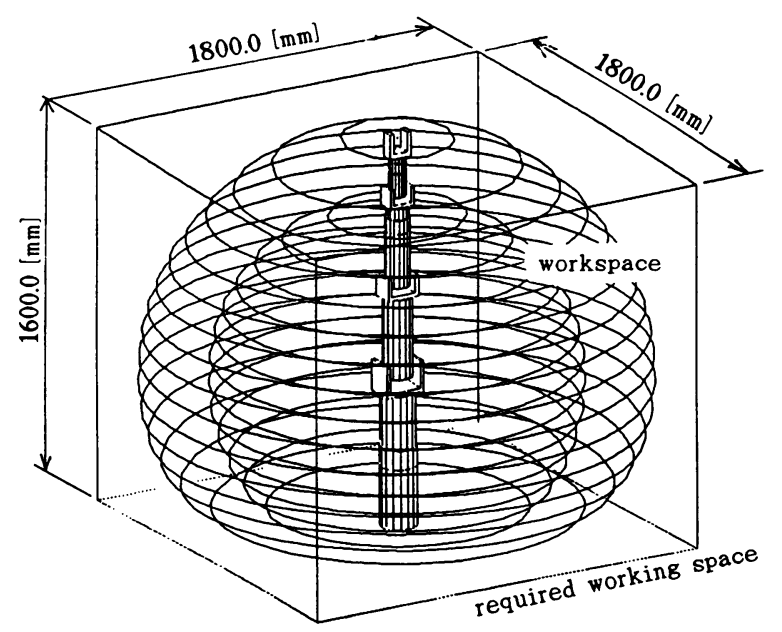

Fig. 9 Required working space given as design condition and workspace of designed robot

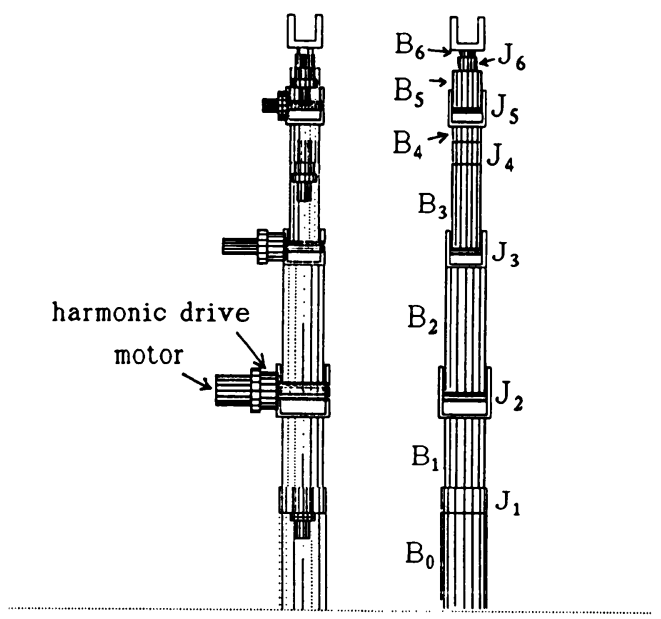

Fig. 10 Designed robot using "TOCARD" 


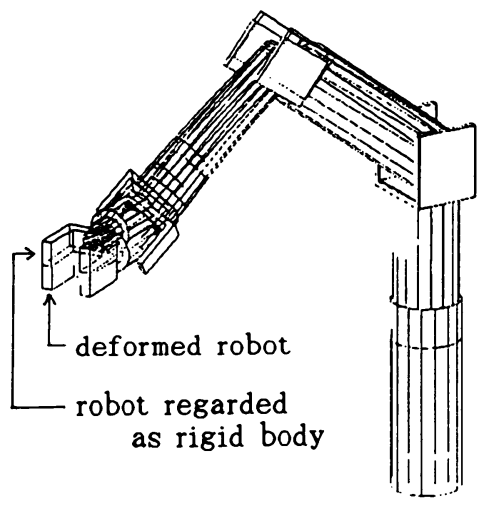

Fig. 11 Maximum deflection (0. $468[\mathrm{~mm}]$ ) on given trajectory of designed robot

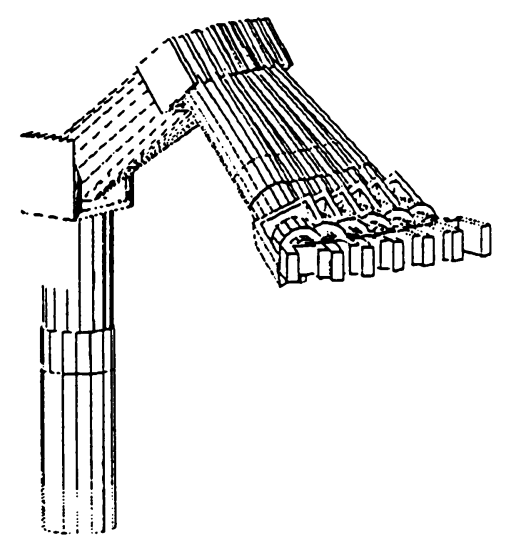

Fig. 12 Minimum natural frequency $(25.0[\mathrm{~Hz}])$ on given trajectory of designed robot
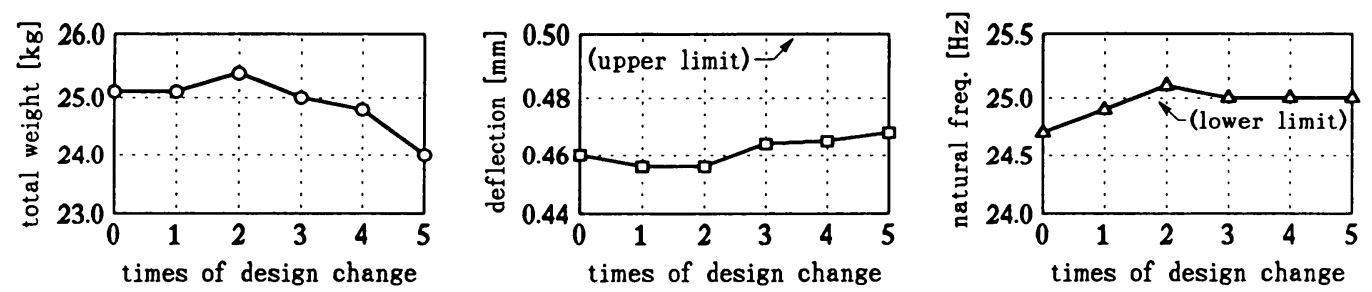

Fig. 13 Change in total weight, deflection and natural frequency with iteration of optimal design steps in detailed structure design stage

の性能をFig. 8, Fig. 9, Fig. 11, Fig. 12, Table 6にまとめる.

Fig. 13 は，詳細設計において設計変更を繰り返したときの ロボットの全重量, たわみ，固有振動数の変化を示している. 図のように，少ない設計変更回数で，たわみ，固有振動数を設 計条件の許容範囲内に収めつつ, 約 $1.1[\mathrm{~kg}]$ の軽量化を図るこ とができた

\section{8. おわりに}

本研究では，ロボットの総合 CAD システム“TOCARD”を 開発した. “TOCARD”の特徵を以下にまとめる.

1）ロボットのメカニズムの設計を目的とする. 特に, 基本 機構から内部機構に至るまでのあらゆる設計パラメータ の設計を一貫して行う.

2) 目的とする単一あるいは複数の作業を実現できるロボッ トを設計する。

3）設計パラメータと設計のための評価量の関係を調べた結 果, 基本機構は運動学的評価に, 内部機構は力学的評価 に関係が深いことが明らかになった．そこで，ロボット の設計を運動学的評価に基づく基本機構の設計と力学的 評価に基づく内部機構の設計とに分けることにより，設 計システムを簡単にしている.

4）ロボットを効率よく設計するために，設計システムは, 内部機構の設計をさらに 2 段階に分けた基本機構設計, 内部機構設計, 詳細設計の 3 段階から成り, 各段階で局 所的な最適化を図る.

5）設計者による設計変更と評価を繰り返す対話的設計を基 本とし，これを支援する独自の設計手法を有する.
6）設計に必要な解析のためのロボット・シミュレータ，およ び機械要素をカタログから選定するための機械要素デー タベースとその作成ツールも備えている.

また, “TOCARD”を用いてロボットの設計を行い, システ ムの有用性を検証した。

“TOCARD”を用いることにより，目的作業に適した機能と 性能を持つロボットを設計できるとともに，設計に要する時 間，費用を節約することが可能となる.

\section{参考 文 献}

[1] V. Potkonjak, M. Vukobratovic and D. Hristic: "Interactive Procedure for Computer-Aided Design of Industrial Robots Mechanisms," Proc. 13th I. S. I. R., pp. 16-85-94, 1983.

[2] V. Potkonjak and M. Vukobratovic: "Computer-Aided Design of Manipulation Robots via Multi-Parameter Optimization," Mechanism and Machine Theory, vol. 18, no. 6, pp. 431-438, 1983.

[ 3 ] D. C. H. Yang and T. W. Lee: "Heuristic Combinatorial Optimization in the Design of Manipulator Workspace," IEEE Trans., SMC-14, 4, pp. 571-780, 1984.

[4] R.G. Fenton and J. Lipitkas: "Optimum Design of Manipulators," Computer-Aided Engineering and Robotics, pp. 68-73, 1984.

[5] C. D. Lin and F. Freudenstein: "Optimization of the Workspace of a Three-link Turning-Pair Connected Robot Arm," Int. J. Robotics Research, vol. 5, no. 2, pp. 104-111, 1986.

[6] R. Vijaykumar, K. J. Waldron and M. J. Tsai : "Geometric Optimization of Serial Chain Manipulator Structures for Working Volume and Dexterity," Int. J. Robotics Research, vol. 5, no. 2, pp. 91-103, 1986.

[7] A. G. Erdman, T. Thompson and D. R. Riley: "Type Selection of Robot and Gripper Kinematic Topology Using Expert System," Int. J. Robotics Research, vol. 5, no. 2, pp. 183-189, 1986.

[ 8 ] P. Chedmail : "Robot Structures And Actuators Optimization," 
Proc. 16th I. S. I. R., pp. 185-195, 1986.

[9] B. Paden: "Optimal Kinematic Design of 6R Manipulators," Int. J. Robotics Research, vol. 7, no. 2, pp. 43-61, 1988.

[10] C. M. Gosselin and M. Guillot: "The Synthesis of Manipulators with Prescribed Workspace," ASME, J. Mechanical Design, vol. 113, pp. 451-455, 1991.

[11] C. J. J. Paredis and P. K. Khosla: "Kinematic Design of Serial Link Manipulators from Task Specifications," Int. J. Robotics Research, vol. 12, no. 3, pp. 274-287, 1993.

[12] J. Kim and P. K. Khosla : "A Formulation for Task Based Design of Robot Manipulators,” Proc. IROS '93, pp. 2310-2317, 1993.

[13] 琴坂, 松元, 高田, 淺間, 平岡 : “保全ロボット用設計支援システム一第 1 報 作業性を考慮した機構の評価”, 1990 年度精密工学会秋季大会学 術講演会論文集, pp. 565-566, 1990.

[14] 琴坂, 松元, 高田, 淺間, 平岡 : “保全ロボット用設計支援システム一第 2 報 作業の方向性を考慮した総合的機構評価”, 1991 年度精密工学会 秋季大会学術講演会論文集, pp. 119-120, 1991.

[15］井上健司：“ロボットの運動学・動力学シミュレータ”, 日本機械学会, no. 900-76, pp. 71-78, 1990.

[16] M. Takano: "A New Effective Solution for Inverse Kinematics Problem (Synthesis) of a Robot with Any Type of Configuration," J. Fac. Eng. Univ. Tokyo (B), vol. 38, no. 2, pp. 107-135, 1985.

[17] 井上, 高野, 佐々木: “ロボットの CAD システムの開発研究一第 5 報 逆運動学を利用した作業領域の計算法”, 1989 年度精密工学会秋季大 会学術講演会論文集, pp. 279-280, 1990.

[18] J. Y.S. Luh, M. W. Walker and R. P. C. Paul: "On-line Computational Scheme for Mechanical Manipulators," J. Dynamic Systems, Measurement, Control, vol. 102, pp. 69-76, 1980.

[19］井上, 高野, 佐々木: “感度を利用した動力学に基づくロボット構造の 最適設計システム”, 日本ロボット学会誌, vol. 9, no. 1, pp. 18-28, 1991.

[20] K. Inoue, M. Takano and K. Sasaki : "Type Selection of Robot Manipulators Using Fuzzy Reasoning in Robot Design System," Proc. IROS '93, pp. 926-933, 1993.

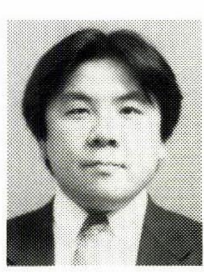

\section{井上健司（Kenji Inoue）}

1963 年 10 月 10 日生. 1988 年東京大学大学院工学 系研究科修士課程修了. 同年, 東京大学工学部助 手. 1993 年大阪大学工学部助手. 1995 年より同学 部講師となり現在に至る。ロボット設計システ ム, 超冗長マニピュレータ, 移動型マニピュレー 夕の研究に従事. 博士 (工学). 精密工学会会員.

(日本ロボット学会正会員)

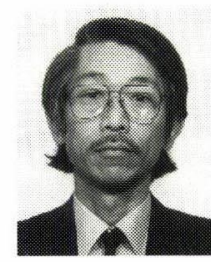

高野政晴（Masaharu Takano）

1936 年 11 月 25 日生. 1963 年 3 月東京大学大学院 工学系研究科修了. 以降東京大学助手, 講師, 助 教授を経て現在に至る。専門はロボットの機構, 運動制御，振動一般問題，および運動の高速化技 術. 精密工学会, 日本機械学会, 日本騒音制御工 学会, 等の会員.

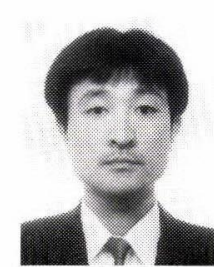

椎名建一（Ken'ichi Shiina）

1965 年 4 月 8 日生. 1988 年電気通信大学電気通信 学部材料科学科卒業. 同年, 川崎製鉄 (株) 入社. 1991 年から 2 年間東京大学工学部に留学. 1994 年 より川崎情報システム(株)に出向, 現在に至る. ネットワーク事業に従事. 工学士

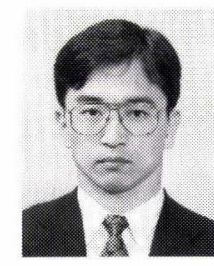

\section{佐々木健（Ken Sasaki）}

1957 年 1 月 15 日生. 1982 年東京大学大学院精密 機械工学専攻修士課程修了. 同年, 日本電気 (株) 入社. 1985 年東京大学工学部助手. 現在, 同学部 助教授. 触覚センサ, 多指ハンドのマニピュレー ション，超音波センサの研究に従事．精密工学会 会員.

（日本ロボット学会正会員） 